\title{
Kabang: the living boat
}

Kabang: the living boat

Kabang : el barco viviente

\section{Narumon Hinshiranan}

\section{OpenEdition}

\section{Journals}

Electronic version

URL: https://journals.openedition.org/tc/310

DOI: $10.4000 /$ tc. 310

ISSN: 1952-420X

\section{Publisher}

Éditions de l'EHESS

\section{Printed version}

Date of publication: 1 January 2001

Number of pages: 499-507

ISSN: 0248-6016

\section{Electronic reference}

Narumon Hinshiranan, "Kabang: the living boat", Techniques \& Culture [Online], 35-36 | 2001, Online since 10 September 2012, connection on 29 September 2022. URL: http://journals.openedition.org/tc/ 310 ; DOI: https://doi.org/10.4000/tc.310

This text was automatically generated on 29 September 2022

All rights reserved 


\title{
Kabang: the living boat
}

\author{
Kabang: the living boat \\ Kabang : el barco viviente
}

Narumon Hinshiranan

1 While the majority of world population are land-based, living in fixed abodes, there are people who preferred to pursue a different lifestyle. Nowadays, several groups of Southeast Asian boat nomads venture the sea and retain their nomadic marine life despite waves of change brought about by market economy, formation of nation state with clear-cut boundary, state policy on settling nomadic indigenes, urbanization and coastal/islands land grabs, ethnic and religious struggles for self-autonomy and political freedom.

2 Although often referred to as sea nomads or sea gypsies, these people do not wander aimlessly across the sea. Instead, they usually have specific island(s) with which they associate and base themselves. The three main groups of sea nomads in Southeast Asia are the Bajau ${ }^{2}$ of the Sulu Archipelago in the Philippines and Sulawesi in Indonesia ; the Orang Laut or Urak Lawoi of coastal areas, straits, and islands in Indonesia, Malaysia, and Thailand ; and the Moken ${ }^{3}$ of the Mergui Archipelago in Myanmar and Thailand.

\section{The dynamics of nomadism}

3 These groups of sea nomads have different degree of « wanderlust ». That is, the level of marine «nomadism » varies both from group to group and even within the group itself. For the Bajau, there are groups who prefer to remain within the reef areas and there are groups which, «travel great distances during annual fishing cycles. Some go as far north as Manila, to the eastern coasts of Mindanao, to Sulawesi, and to the waters of Borneo » (Nimmo 1986 : 35).

4 The five Moken sub-groups of Dung, Jait, Lebi, Naywi, and Chadiak have their own «mother islands » as the base but often travel to outlying « satellite » islands (Ivanoff $1986: 11,13,174)$. It has been observed since a century ago that the Moken generally confine themselves to their own subgroup (Anderson $1890: 8$ ). The observation should 
hold true since the Moken have developed their own sub-dialects ${ }^{4}$ under the name of mother island or groups of island belonging to each sub-group.

In addition to the different degree of nomadism, these sea nomads have different travel group composition. Among the Bajau, it was found that the marine expedition carried out by the Tabauwan people are in all-male team, leaving for several weeks whereas some of the Siasi and Zamboanga Sama go in flotillas of family houseboats (Nimmo 1986 : 35). The Urak Lawoi (Orang Laut of Phuket, Lanta, and Lipeh islands) of southern Thailand stated that their nomadic boat trips rarely include women. Though their marine expedition sometimes take them as far as the islands in Myanmar, and take as much as three or four weeks, the Urak Lawoi women wait on shore.

6 At present, the Moken of the Surin Islands in Thailand ${ }^{5}$ are perhaps the only sea nomads group representing the widest gamut of nomadism. In other words, within their own group, there are families who settle down and live in bamboo huts all year round, venturing into sea occasionally in search of subsistence. And there are families (fewer in number) who adopt the Surin Islands as their temporary shelter during rainy season, but return to the nomadic boat life and continue island-hopping every dry season (Hinshiranan 1996). Furthermore, the Surin Moken have various forms of marine expedition - either one boat or flotillas of all-male team, mixed team (males and females), to a single family.

\section{Kabang : the heart of Moken nomadic life}

7 Man and boat are one and the same in nature and this reminds them that without their boats they are no longer either nomads or Moken (Ivanoff $1999: 32$ ).

8 Nomadic marine livelihood is virtually impossible without a boat. The boat is an essential part of sea nomads life, it serves as a tool for transportation, fishing, as an abode, and often as a place of birth and death (photo 1). It has been stated that the boat sometimes serve as Moken's coffin (Anderson 1890:31). However, the statement remained unconfirmed (Ivanoff 1999: 17), and Moken's boat coffin seems to be different from the practice of burial in boat-shaped coffins which has been found elsewhere in insular southeast Asia (Howard 1998).

The Moken use two kinds of boats: kabang or the large dug-out boat which serves as dwelling place, and chapan or small row boat which can cover a short distance travel or foraging. Kabang is also a general term for other boats, for example, kabang tchepao (large boat), kabang paiwo (fiberglass boat or speed boat), kabang auen lak (trawler boats), etc.

10 In Moken community, there is no boat that is constructed by a group of people, or owned communally. Kabang is built and owned by individual family, sometimes with the help of relatives and friends. The boats are made entirely by basic tools, namely axes and multi-purposed adzes ${ }^{6}$. A tree will be particularly selected for boat-making. Before it is cut down, a praying to the spirits of the forest is made and due respect is given to the guardian spirit of the tree, the Moken « question the tree as if it were a living being. Will it agree to be cut down? (Ivanoff $1999: 29$ ).

11 The tree is then logged and hollowed in situ as the log is too heavy to haul out of the forest. Only when the hull takes shape, do the Moken haul it out to finish up on shore. Communal help is recruited for log hauling task and practically the whole community 
joins in this event with " oh hela, oh oh hela " or beautiful rhythmic calls to harmonize the tugging and towing of this hollowed log. Smaller logs for the chapan may be hauled to shore and hollowed out on the beach. Then, the slow fire is built under the dug-out and after the wood becomes softer and more flexible by the heat, the sides are stretched out and widened. The firing and hollowing are repeated until the dug-out is wide enough to serve as a boat hull. Each step of boat making is a difficult task in itself, one that requires skills, strength, patience, and faith! A few Moken broke their hollowed logs during the down-hill hauling, and a few cracked their boat during hullstretching and widening (photo 2).

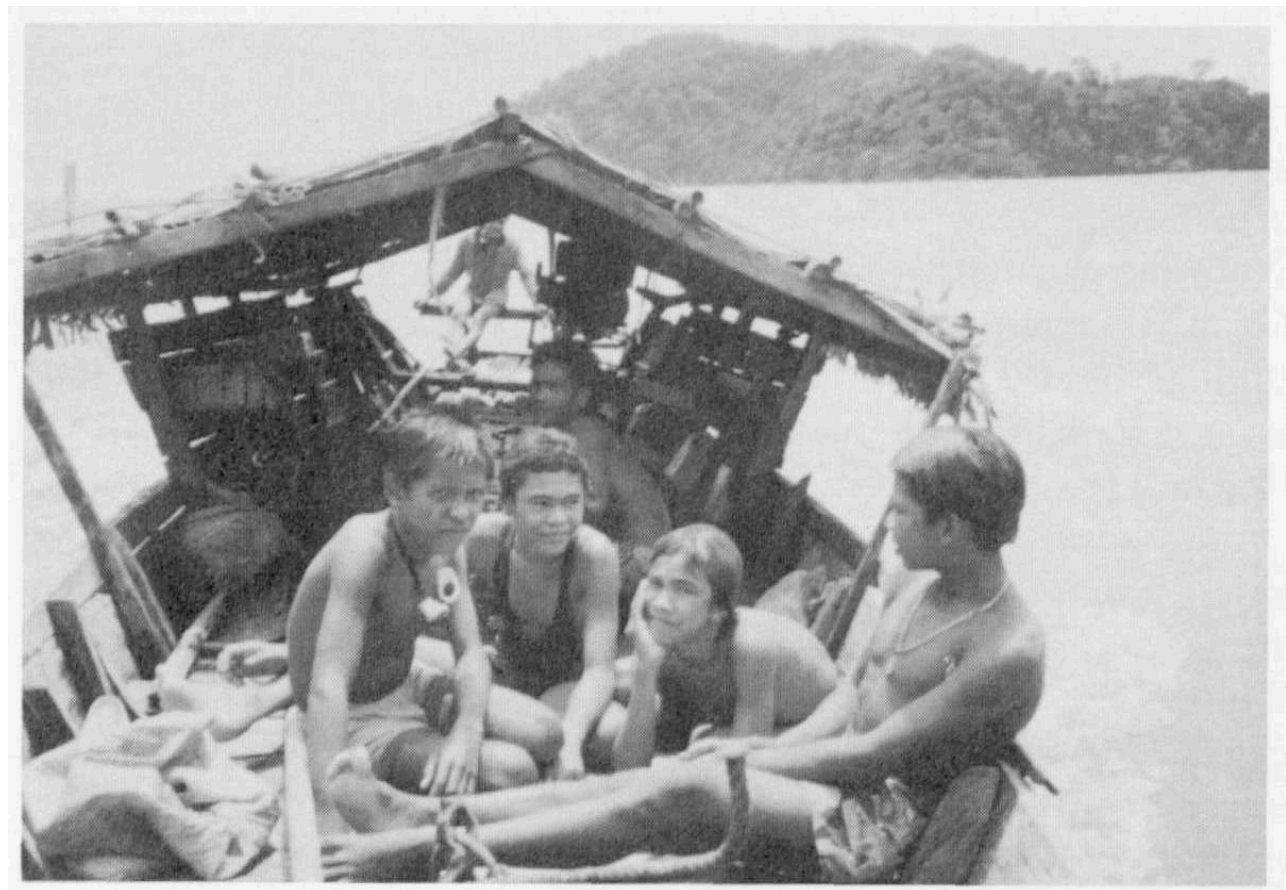

PHOTO 1. MOKEN ALL-MEN EXPEDITION TO ISLANDS WITHIN THE SURIN ARCHIPELAgO 


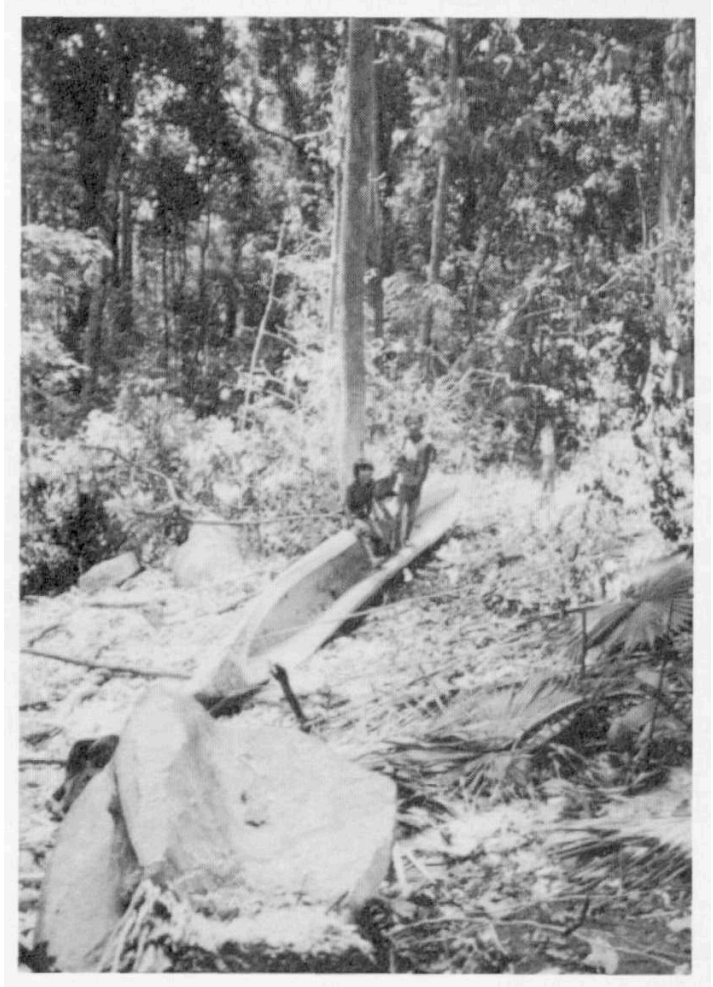

PHOTO 2. THE LOg IS HOLLOWED OUT IN THE FOREST UNTIL THE HULL TAKES SHAPE, THEN IT WILL BE HAULED OUT FROM THE FOREST

The unique characteristic of earlier kabang is zalacca woodstem (Zalacca wallichiana) gunwales secured by rattan cords. The stem is long and light, thus Moken zalacca kabang is known as "unsinkable» boat because of its bouyancy. During stormy weather, kabang can be hauled up onto the beach because zalacca wood become even lighter when dry. Nowadays kabang gunwales are made with wood planks which are much more durable than zalacca stems. Plank boats are much more widespread among the Moken that only a few zalacca boats can be seen in further north in the Islands of Lord Lougborough and Sullivan.

In the old days, kabang was equipped with a rectangular sail made with long pandanus leaves sewed together with rattan cord, and spearhead-shape oars are also used. In these days, planked kabang become too heavy to equip with sail, so diesel motor replaced sail and oars.

14 Another striking feature of kabang is forked ends (prow and stern) or bifurcation which may serve several functional roles as foot-board to step in and out of boat and as « handle» to pull the boats onto the beach. This bifurcation may also serve a deeper symbolic and cultural meaning (Ivanoff $1999: 109-113)$ or suggests the affinity with the boat of other maritime groups in Southeast Asia (Sopher 1977 : 196). Notch prow has been found on water crafts $^{7}$ in different parts of Southeast Asia and Oceania and the feature might reflect « cultural survival » of an ancient boat form.

Both kabang and chapan requires regular maintenance. This includes puttting a small fire under the bottom of the boat " mayun kabang » to get rid of algae and make the boat run faster or «bo talao », caulking and adding more wood resin to seal any crack and to prevent leakage, replacing worn-out pandanus roof, etc. (photo 3). 
To outsiders' eyes, all kabang may look the same. Nontheless, each kabang has a distinctive characteristic in the Moken's eyes and they can identify whose kabang it is from afar.

\section{Ritual Boats}

The Moken have the real kabang for their daily use and the miniature one for special ritual. The miniature kabang is built with zalacca wood and released in the sea to float away misfortune and to appease the spirits. Before releasing the boat, each Moken family put some rice, betel nut and pepper leaves in the boat. Boat releasing ritual is sometimes held together with the celebration of ancestor's spirit posts on the fifth lunar month.

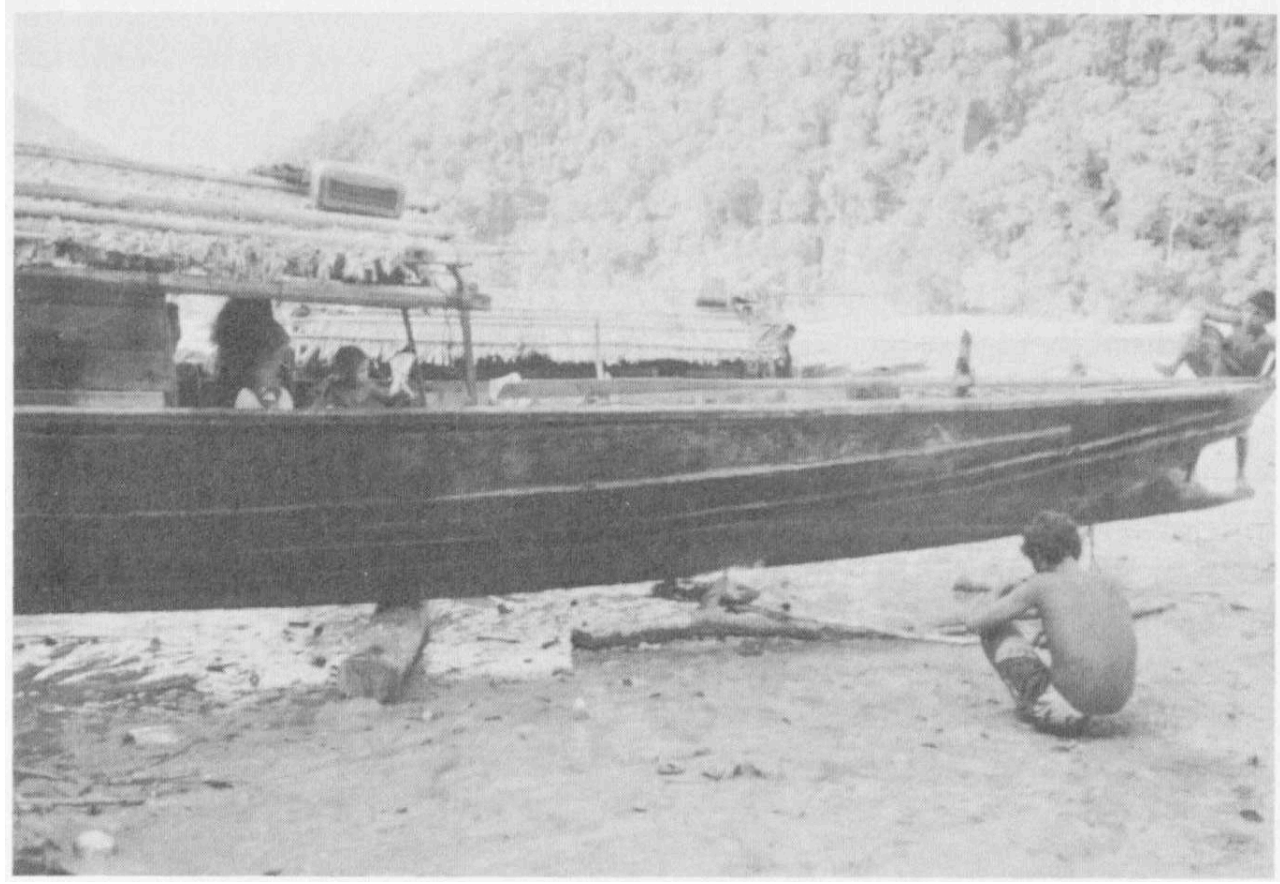

PHOTO 3. A MOKEN MAN PUTS A SMALL fIRE UNDER HIS BOAT TO RID OFF ALgAE WHILE HIS WIFE IS COOKINg ON THE BOAT AND HIS DAUgHTER IS CLIMBINg UP THE PROW STEP

In Phuket and Lanta islands, the Urak Lawoi boat releasing ritual has been a wellknown and well-attended event in the sixth and eleventh lunar months. Urak Lawoi also made elaborated zalacca boat with raised stern platform of split bamboo, and equipped with white cloth sail. The boat is filled with miniature oars, harpoons, bales, cooking pot, stove, and gong used as boat signal (Aporn $1989: 148,152$ ).

However, boat releasing ritual is not unique to the Moken and Urak Lawoi, it is a grand celebration in the Muslim community in southern Thailand as well. It was noted that the ritual was held for three days in the community, together with boat racing and kite competition, spirit offerings were made. And, on the last day of the celebration, the half of the buffalo and the other food that the Bomo has been preparing for sacrifice are placed on the bamboo raft and pushed out as far as the men and boys crowded around it can go. At this point, one or more Kolek, each with a minimum crew, take over and tow the raft far out to sea. It is generally considered that this offering is for the Hantu Laut or evil sea spirits (Fraser 1960 : 187-188). 
20 Although Moken, Urak Lawoi, and the Thai-Muslim boat releasing rituals are similar in essence, the crucial differing element is their boat forms. While the Moken build miniature ritual boat in the form of zalacca kabang with bifurcated ends, the Urak Lawoi's boat is one with elongated bow and raised stern, and the Thai-Muslim build bamboo raft for this particular ritual.

Why should one concern about the form of ritual boat? Because it represents some «cultural survival ». Nowadays all Urak Lawoi have adopted the use of Thai Rua Hua Thong and their traditional boat is re-created only in this boat-releasing ritual. The Moken of the Surin Islands gradually adopt the use of Rua Hua Thong, and 7 out of 18 Moken boats in the Surin Islands are Rua Hua Thong and not traditional kabang. As plank boats gradually replaced zalacca boats, now the trend is towards Rua Hua Thong either purchased from the shore or given to the Moken by the Thais. In Myanmar, the Moken also adopt Burmese boat and modify it into livable kabang. Is it possible that in the near future, traditional kabang can only be seen in the ritual? (photo 4).

\section{Disappearing kabang disappearing Moken ?}

Approximately 4-5 decades ago, the Moken did more travelling on their zalacca kabang with pandanus sail. They frequently visited friends and relatives on different islands in a fleet of 5-20 kabang. Since they have begun using long-tailed motor with their plank boats, they rarely travel in fleets mainly due to the cost of diesel oil. Thus, apparently they cover less distance and become less mobile as a group. Yet the Moken never lose their identity as the sea nomads as they still maintain their individual mobility and free spirit.

Even though the Moken adopt the use of other boat forms, they still maintain the knowledge of building traditional kabang. It holds true today as Anderson (1890) observed over a century ago, Moken men are able to build a model of kabang " true to scale down to small details, without the use of a foot-rule or similar device " (photo 5).

Ivanoff made a keen observation on the Moken and their seemingly disappearing culture as, "Always described as being in distress, about to disappear, it is still very much alive ». He asserts that, « the flexibility of Moken society, its capacity to integrate the culture of others without disappearing, is a cultural force " (Ivanoff $1997: 121$ ). On the other hand, in his later work he suggested that, «The boat represented Moken society and enabled all members to keep their culture alive by accomplishing the social ritual of construction of the boat " $(1999: 136)$. Traditional kabang is thus more than a boat form, it is a symbolic structure which embodies nomadic ideology and cultural pride. Living kabang might then be essential factor in keeping the Moken society alive as well. 


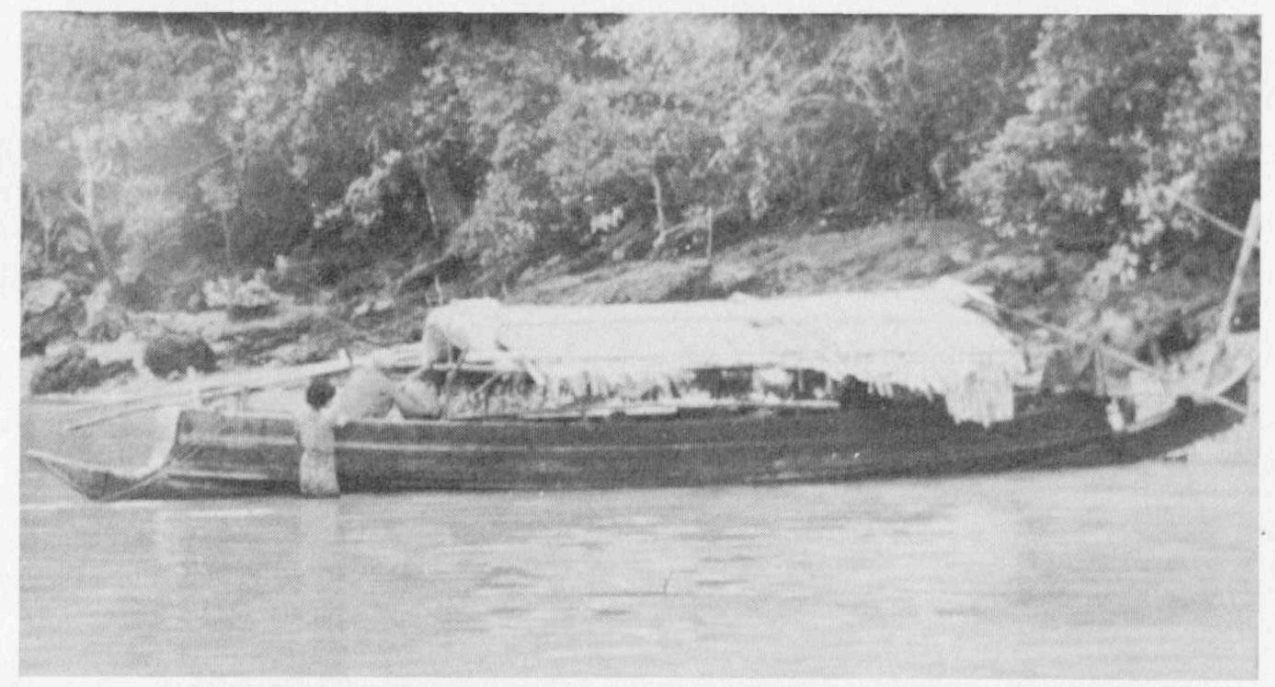

Photo 4. Burmese boat adopted for use and adapted as « houseboat » by the Moken in Myanmar

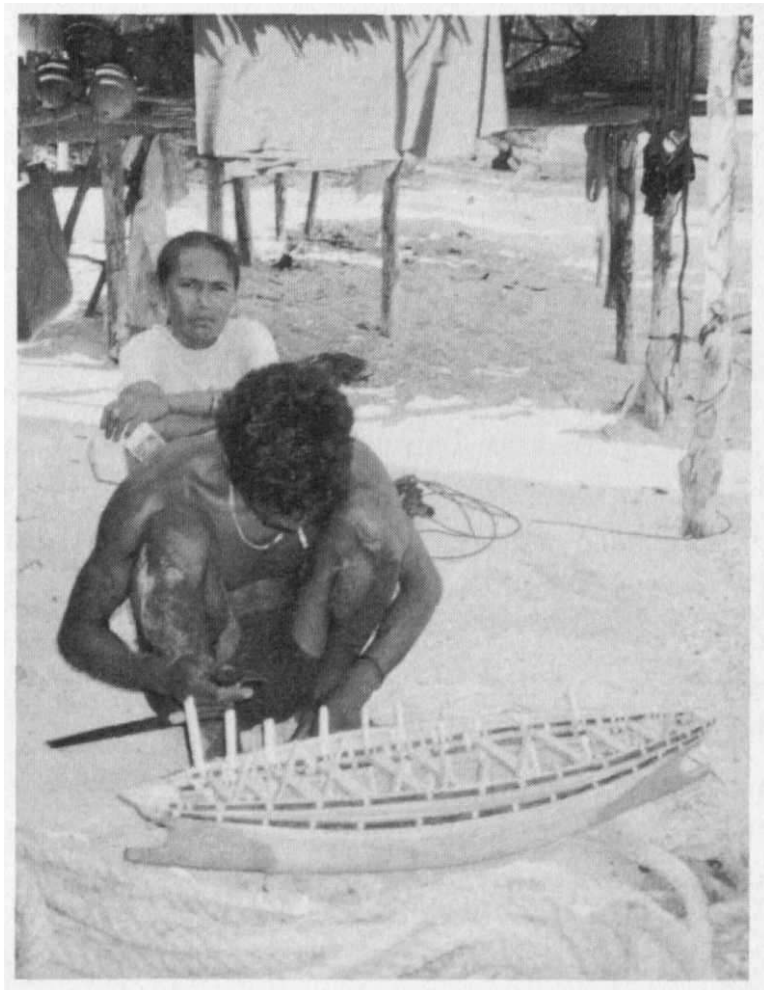

Photo 5. A Moken man builds a miniature zalacca kabang while his wife looks on

\section{BIBLIOGRAPHY}

Anderson, John, 1890, The Selungs of the Mergui Archipelago. London : Trubner \& Co. 
Aporn u-Krit, 1989, The Boat Floating Ritual : A Reflection of the Social and Cultural Life of Chao Le. Unpublished M.A. thesis, Department of Anthropology, Silpakorn University.

Fraser, Thomas M. Jr., 1960, Rusembilan : A Malay Fising Village in Southern Thailand. Ithaca : Cornell University Press.

Narumon, Hinshiranan, 1996, The Analysis of Moken Opportunistic Foragers' Intragroup and Intergroup Relations. Unpublished Ph.D. Dissertation, University of Hawaii.

Horridge, Adrian, 1985, Sailing Craft of Indonesia. New York : Oxford University Press.

Howard, Michael C., 1998, « The Canoe Bow Decorations (Muka Perahu) of Northern Irian Jaya », Arts of Asia 28 (3) : 89-101.

Ivanoff, Jacques, 1986, « Les Moken, literature orale et signes de reconnaissance culturelle », Journal of the Siam Society $74: 9-20$.

1997, Moken, Sea-Gipsies of the Andaman Sea Post-war Chronicles. Bangkok : White Lotus., 1999, The Moken Boat : Symbolic Technology. Bangkok : White Lotus Press.

Nimmo, H. Arlo, 1986, « Recent Population Movements in the Sulu Archipelago : Implications to Sama Culture History », Archipel 32.

Sopher, David E., 1977, The Sea Nomads. Singapore : National Museum of Singapore.

White, Walter G., 1922, The Sea Gypsies of Malaya. London : Seeley, Sevice \& Co. Ltd.

\section{NOTES}

2. Sometimes called Bajo, Badjao, or Sama.

3. Spelling variation includes Mawken, Mawkhen; In Myanmar they are called Selung, Silong, or Selon.

4. These dialects are distinguished by accent and vocabulary difference.

5. The Surin Moken consist of those from Dung and Chadiak subgroups.

6. Adze blade position can be changed by placing it upright or on its side, this ingenious usage as « iron is rare and expensive for the nomads » (Ivanoff 1999 : 47-48).

7. For example, «elephant-fish» or gadja-mina boat with eyes, nose (or trunk) and ear, and various other types of Indonesian sailing crafts (Jukung, Lisalis, Jangolan, Perahu Jabar - from the drawings of sailing crafts in Horridge 1986) which have extended keel at prow and stern. These elongated parts resemble kabang bifurcation.

\section{ABSTRACTS}

The Moken have been marine nomadic people for at least two centuries, so they are naturally skillful seafarers and boat-builders. Decades ago, wooden planks and engine gradually replaced zalacca stems and pandanus sail. The Moken kabang are now more durable, but at the same time, more difficult to build and more costly to equip and run the engine. This paper examines aspects of socio-cultural change entailing the change in boat materials and form. 
Les Moken sont des nomades marins depuis plus de deux siècles; ils sont donc naturellement experts en navigation et en charpenterie navale. Il y a plusieurs décennies, les planches et le moteur ont progressivement remplacé les stipes du palmier zalacca et les voiles faites avec le palmier pandanus. Le kabang moken est de ce fait plus solide maintenant, mais sa construction est plus complexe et il est plus coûteux à équiper. Cet article examine les changements socioculturels induits par l'évolution technique des bateaux.

Los Moken son nómades marinos desde hace más de dos siglos; son por lo tanto naturalmente expertos en navegación y en carpentería naval. Hace varios decenios que las tablas y los motores han reemplazado progresivamente los estípites de palmera Zalacca y las velas hechas con palmera Pandanus. Es por esa razón que el Kabang moken es ahora más sólido, pero su construcción es más compleja, y es más costoso equiparlo. Este artículo examina los cambios socio-culturales inducidos por la evolución técnica de los barcos.

INDEX

Mots-clés: bateau, changements socio-culturels, kabang, Moken, nomades marins.

\section{AUTHOR}

\section{NARUMON HINSHIRANAN}

Chulalongkorn University, Social Research Institute, Phyathai Road, Pathumwan, Bangkok 10330, Thailand 